\title{
The Human Right to Health and HIV/AIDS: South Africa and South-South Cooperation to Reframe Global Intellectual Property Principles and Promote Access to Essential Medicines
}

Erika George

University of Utah, S. J. Quinney College of Law

Follow this and additional works at: https://www.repository.law.indiana.edu/ijgls

Part of the Human Rights Law Commons, Intellectual Property Law Commons, International Law Commons, and the Medical Jurisprudence Commons

\section{Recommended Citation}

George, Erika (2011) "The Human Right to Health and HIV/AIDS: South Africa and South-South Cooperation to Reframe Global Intellectual Property Principles and Promote Access to Essential Medicines," Indiana Journal of Global Legal Studies: Vol. 18 : Iss. 1 , Article 8.

Available at: https://www.repository.law.indiana.edu/ijgls/vol18/iss1/8

This Symposium is brought to you for free and open access by the Law School Journals at Digital Repository @ Maurer Law. It has been accepted for inclusion in Indiana Journal of Global Legal Studies by an authorized editor of Digital Repository @ Maurer Law. For more information, please contact rvaughan@indiana.edu.

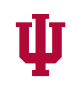

JEROME HALL LAW LIBRARY

INDIANA UNIVERSITY Maurer School of Law
Blooming ton 


\title{
The Human Right to Health and HIV/AIDS: South Africa and South-South Cooperation to Reframe Global Intellectual Property Principles and Promote Access to Essential Medicines
}

\author{
ERIKA GEORGE*
}

\begin{abstract}
The HIV/AIDS pandemic has had a devastating and disproportionate impact in countries of the Global South. The experience of an individual infected with HIV in Africa is very different than that of an individual infected with HIV in America. Life expectancy varies sharply. The ability or inability to access medicines essential for treatment accounts for much of the variance. This article examines how the rhetoric of human rights used in the context of South Africa's AIDS crisis resonated across the Global South, resulted in a powerful social movement for access to medicines, and contributed to important changes in international intellectual property law principles. This article first introduces the competing commitments governments of the Global South face with a discussion of the current status of the global AIDS epidemic and an explanation of the structure and content of the international intellectual property and human rights legal systems. This article then provides a discussion of how domestic civil society activists organized to oppose international intellectual property interests through law and politics using the language of international human rights. Next, it presents an interpretation of how events in South Africa led to the Doha Declaration and strengthened the emerging alliance between countries of the Global South. Finally, it identifies lessons to be learned from the experience of these actors.
\end{abstract}

* Professor of Law, University of Utah, S.J. Quinney College of Law. J.D., Harvard Law School; M.A., University of Chicago; B.A., University of Chicago. I extend my appreciation to Leslie Francis, Teneille R. Brown, Kali Murray, Cynthia Ho, Ruth Okedhi, and Kenneth Chahine for their helpful insights. An earlier draft of this article was presented at the International Studies Association (ISA)-Brazilian Association of International Relations (ABRI) Joint International Meeting on Diversity and Inequality in World Politics in July 2009 at PUC-Rio de Janeiro, Rio de Janeiro, Brazil. I would also like to acknowledge Jennifer Ku, Robert Spjute, Razvan Ungureanu, and Deb Buckley for their excellent research assistance.

Indiana Journal of Global Legal Studies Vol. 18 \#1 (Winter 2011)

(C) Indiana University Maurer School of Law 


\section{INTRODUCTION}

Human rights are understood to be universal. Everyone, everywhere is entitled to enjoy the fundamental rights contained in international legal instruments such as the Universal Declaration of Human Rights; the International Covenant on Economic, Social, and Cultural Rights; the International Convention on the Rights of the Child; and the African Charter of Human and Peoples' Rights. Each of these instruments recognizes health as a fundamental human right. International institutions such as the World Health Organization (WHO) and the United Nations Children's Fund (UNICEF) have partnered to promote public health. However, despite its recognition in international law and its promotion by international institutions, the human right to health remains unrealized for many.

The international AIDS pandemic has had an especially devastating and disproportionate impact in the Global South. ${ }^{1}$ Across all countries the disease seems to affect or infect the most vulnerable people in a population-women, children, and members of disfavored or disadvantaged groups. The strong intersection between identity and infection across countries and within societies implicates deep global inequalities. For example, to be infected in South Africa is very different than being infected in the United States of America; life expectancy varies greatly, as does access to treatment. ${ }^{2}$ One of the most difficult public health challenges for certain countries in the Global South is ensuring access to affordable treatment and medicines for people who are HIV-positive.

While access to medicines is an essential component of the right to health, globally almost two billion people lack access to essential medicines. ${ }^{3}$ In December 2009, only thirty-six percent of people living with HIV in low- and middle-income countries were receiving treatment. ${ }^{4}$ Individuals who do not receive treatment early can become resistant to first-line medications that treat $\mathrm{HIV}$, requiring second-line

1. The term "Global South" is used in this instance to refer to developing nations in portions of Africa, Asia, and Latin America.

2. Richard Hunt, HIV and Aids: Statistics, U.S.C. SCH. OF MED. MICROBIOLOGY \& IMMUNOLOGY ON-LINE, http://pathmicro.med.sc.edu/lecture/hiv5.htm.

3. U.N. Human Rights Council (H.R.C.), Report of the Special Rapporteur on the Right of Everyone to the Enjoyment of the Highest Attainable Standard of Physical and Mental Health, 11th Sess., ๆ 14, U.N. Doc. A/HRC/11/12 (Mar. 31, 2009) (by Anand Grover) (citing World Health Organization [WHO], WHO Medicines Strategy: Countries at the Core, 20042007 (2004)).

4. WHO, Progress Report 2010: Towards Universal Access: Scaling Up Priority HIV/AIDS Interventions in the Health Sector 53 (2010), available at http://www.who.int/hiv/pub/2010progressreport/report/en/index.html. 
treatments that can cost up to nine times as much as earlier treatment options. $^{5}$

In 1994, the international community, struggling to cope with an emerging global pandemic, founded the Joint United Nations Programme on HIV/AIDS (UNAIDS). That same year the World Trade Organization (WTO) was also created. The WTO Agreement on TradeRelated Aspects of Intellectual Property Rights (TRIPS) revolutionized global patent law. Among other things, TRIPS countries are required to standardize recognition of patents and to protect intellectual property rights against infringement. After the TRIPS expansion of patent protection to pharmaceutical products and processes, countries in the Global South found their ability to promote public health compromised by the prohibitively high cost of the patented drugs used to treat AIDS and its associated opportunistic infections. ${ }^{6}$

A legal challenge brought against the government of South Africa by pharmaceutical manufacturers to force the country to bring its laws into compliance with TRIPS was met with significant resistance from civil society. ${ }^{7}$ The suit and subsequent social unrest served to raise global awareness of the potentially negative public health consequences of strong patent protections in the context of a developing country experiencing an epidemic disease burden. Resistance to TRIPS from developing nations, primarily South Africa, India, and Brazil, at international meetings of the WTO eventually led to the concessions contained in the Doha Declaration. The Doha Declaration provides that the TRIPS agreement does not prohibit a member country from taking measures to protect public health and to promote access to medicines. ${ }^{8}$ The Declaration also permits the use of compulsory licenses under certain circumstances. ${ }^{9}$

This article will examine how the rhetoric of human rights used in the context of South Africa's AIDS crisis resonated across the Global

5. "At the beginning of treatment, the combination of drugs that a person is given is called first line therapy. If after a while HIV becomes resistant to this combination, or if side effects are particularly bad, then a change to second line therapy is usually recommended. Second line therapy will ideally include a minimum of three new drugs, with at least one from a new class, in order to increase the likelihood of treatment success." Introduction to HIV and AIDS Treatment, AVERT, http:/www.avert.org/ treatment.htm (scroll down to "first and second line therapy").

6. SAfAIDS, Unsung Heroes: WHO Breakthrough on Patents Will Give Poor Countries Better Access to Drugs, 14 SAfAIDS NEWS 2, no. 2, 2008 at 10, http:/www.safaids.net/ files/u1/SAfAIDS_News_June_2008.pdf.

7. William Flanagan \& Gail Whiteman, "AIDS is Not a Business": A Study in Global Corporate Responsibility-Securing Access to Low-Cost HIV Medications, 73 J. BuS. ETHICs 65, 71 (2006).

8. World Trade Organization, The DOHA Declaration on the TRIPS Agreement and Public Health, I 4, WT/MIN(01)/DEC/2 (Nov. 14, 2001) [hereinafter Doha Declaration].

9. Id. I $5(\mathrm{~b})$. 
South, resulted in a powerful social movement for access to medicines, and contributed to important changes in international intellectual property law principles and international pharmaceutical industry practices. Specifically, this article will explore the emergence and efficacy of South Africa's political alliance with India and Brazil to influence legal reform and increase access to medicines essential for treating HIV/AIDS.

I argue that the social movement around access to medicines, as it was organized and deployed in South Africa, has shaped positions of governments and the scope of international law with respect to intellectual property. ${ }^{10}$ South Africa's law and politics with respect to its AIDS crisis has served as an exercise in making claims and articulating obligations with lasting power to influence multiple systems of law. It also has helped to build alliances among other countries in the Global South, specifically India and Brazil. This article presents the Pharmaceutical Manufacturers' Association $v$. The President of the Republic of South Africall lawsuit as an illustration of how norms are being negotiated by countries, communities, and corporations within and between different levels of domestic and international law. The case also illustrates how multiple legal systems can work together or against one another.

Part I of this article introduces the issues with a discussion of the status of the global AIDS epidemic and an explanation of the structure and content of the international intellectual property and human rights legal systems. Part II provides a discussion of how domestic civil society activists organized to oppose international intellectual property interests through law and politics using the language of international human rights. Part III presents an interpretation of how events in South Africa led to the Doha Declaration and strengthened the emerging alliance between South Africa, India, and Brazil. Finally, Part IV identifies lessons to be learned from the experience of these actors and interrogates the role of rights as weapons in what legal anthropologists have termed "lawfare."12

10. See Susan K. Sell \& Aseem Prakash, Using Ideas Strategically: The Contest Between Business and NGO Networks in Intellectual Property Rights, 48 INT'L STUD. Q. 143, 166-67 (2004).

11. Pharm. Mfrs.' Ass'n of S. Afr. v. President of the Republic of S. Afr., Case no. 4183/98, High Court of South Africa (Transvaal Provincial Division).

12. See John L. Comaroff \& Jean Comaroff, Law and Disorder in the Postcolony: An Introduction, in LAW AND DISORDER IN THE POSTCOLONY 1, 26-27 (John L. Comaroff \& Jean Comaroff eds., 2006). Lawfare has also been used in other contexts to describe the use of law as a "weapon" in actual warfare. E.g., What is Lawfare?, THE LAWFARE PROJECT, http://www.thelawfareproject.org/. 
Lessons to be drawn from the pharmaceutical industry's legal action against South Africa and the opposition it drew from activists domestically and internationally may enable us to better understand the potential of power emanating from new places-corporations and communities. While power asymmetry persists in the global system, the conflict over the case also teaches that there are new areas in which to promote human dignity through advancing human rights. This article concludes that the agency of communities deploying rights language and using the law in innovative and inventive ways across the Global South is reason for optimism. By giving voice to viewpoints from the Global South, communities have changed the conversation of the trade in intellectual property to include recognition of rights.

\section{THE GLOBAL HIV/AIDS PANDEMIC, INTERNATIONAL INTELLECTUAL PROPERTY, AND INTERNATIONAL HUMAN RIGHTS}

\section{A. The Global AIDS Epidemic: Epicenter Experiences}

According to UNAIDS, the global AIDS epidemic has been stabilizing since 2000 , but sub-Saharan Africa remains at the epicenter of the epidemic. ${ }^{13}$ According to UNAIDS, sixty-seven percent of people living in the world with HIV reside in sub-Saharan Africa, and seventytwo percent of AIDS deaths occur in the region. ${ }^{14}$ In most regions outside sub-Saharan Africa, men who have sex with men, sex workers, and injecting drug-users are disproportionately affected by HIV/AIDS. ${ }^{15}$ In Africa, HIV prevalence is significantly higher among young women than men. ${ }^{16}$ A disproportionate number of those infected and affected by the AIDS epidemic in Africa are women, ${ }^{17}$ who account for nearly sixty percent of HIV infections in sub-Saharan Africa. ${ }^{18}$

UNAIDS attributes the stabilization in the global percentage of people living with HIV to the positive effects of more widely available antiretroviral therapy. ${ }^{19}$ Previously, people without access to antiretroviral therapy were dying from AIDS. Now, people with access to antiretroviral therapy are living longer with HIV. This was not

13. Joint United Nations Programme on HIVIAIDS [UNAIDS], 2008 Report on the Global AIDS Epidemic, 5, UNAIDS/08.27E/JC1511E (July 2008) [hereinafter UNAIDS].

14. Id.

15. Id. at 9 .

16. Id. at 7 .

17. Id. at 22-23 ("Women account for two thirds of all caregivers for people living with HIV in Africa, and women who are widowed as a result of HIV risk social ostracism or destitution.").

18. Id. at 8 fig.6.

19. Id. at 5 . 
always so. Indeed, antiretroviral therapy may not have been as widely available as it is today had countries and communities in the Global South not joined in alliance to advance arguments for greater access to medicine.

While there has been significant progress toward meeting the challenges associated with the global AIDS epidemic, that progress has been uneven. UNAIDS cautions that "the epidemic's future is still uncertain, underscoring the need for intensified action to move towards universal access to HIV prevention, treatment, care and support." 20 While the epidemic has stabilized, it has done so at high rates of prevalence in some places. In 2007, the rate of HIV prevalence in South Africa was an estimated eighteen percent among people aged fifteen to forty-nine years. ${ }^{21}$

The percent coverage of antiretroviral therapy for adults and children with advanced HIV, while improving significantly, is far from universal and varies widely between nations for various reasons. For example, Brazil enjoys greater than seventy-five percent coverage while South Africa has only achieved between twenty-five percent and fortynine percent coverage. ${ }^{22}$ Achieving universal treatment access by 2015 would reduce the number of projected AIDS orphans, estimated at approximately five million, below current projections. ${ }^{23}$

Nevertheless, according to UNAIDS the number of people receiving antiretroviral medicines in low- and middle-income countries has increased significantly. ${ }^{24}$ Antiretroviral therapy now reaches almost three million people. ${ }^{25}$ Celebrating this expanding access in its most recent report on the status of the global epidemic, UNAIDS acknowledges that " $[\mathrm{m}]$ any actors share credit in this achievement, most notably people living with HIV themselves, whose advocacy helped achieve what was once considered impossible."26 Antiretroviral treatment programs will remain critical for mitigating the epidemic's impact. Because HIV treatment is for life, affordable and sustained treatment programs will be essential over the long term. Ultimately, in addition to preventing new infections, continued progress will require securing more affordable HIV treatments.

20. Id. at 3.

21. U.S. AgENCY FOR INT"L DEv. [USAID], HIV/AIDS HeALTH PROFILE SOUTHERN AFRICA REGION 2 (2008).

22. UNAIDS, supra note 13 , at 26 fig. $29 \mathrm{~b}$.

23. Id. at 24 fig. 28 .

24. Id. at 17.

25. Id.

26. Id. 


\section{B. International Intellectual Property Law}

The protection of intellectual property is mandated by the WTO's TRIPS Agreement. ${ }^{27}$ Established in 1995, the WTO is the multilateral institution charged with administering trade rules among member countries and is the successor to the General Agreement on Tariffs and Trade (GATT). ${ }^{28}$ It serves as a forum for trade negotiations, resolves trade disputes, monitors the national trade policies of its 153 member countries, provides technical assistance and training for developing countries, and cooperates with other international intergovernmental organizations. ${ }^{29}$

As successor to the GATT, the WTO emerged from a series of trade negotiations, or rounds, conducted under the auspices of the GATT. ${ }^{30}$ Countries participating in the Uruguay Round of GATT created the WTO and in the process also achieved a major revision of the original GATT. ${ }^{31}$ Established just after World War II, the GATT was widely perceived to be ill-equipped to address the complexities of a modern global market. 32

The original GATT primarily governed the trade of goods. ${ }^{33}$ The Uruguay Round set forth new rules to govern trade in services, relevant aspects of intellectual property and dispute settlements, and also included trade policy reviews within its negotiated agreements. ${ }^{34}$ As members of the WTO, countries receive assurances that their exports will be treated fairly in foreign markets in exchange for their commitment to extend fair treatment to imports into their own domestic markets. ${ }^{35}$

Major decisions of the WTO are made by the entire membership and by consensus. ${ }^{36} \mathrm{~A}$ ministerial conference of the members convenes at

27. Agreement on Trade-Related Aspects of Intellectual Property Rights art. 3.1, Apr. 15, 1994, Marrakesh Agreement Establishing the World Trade Organization, Annex 1C, 1869 U.N.T.S. 299 [hereinafter TRIPS].

28. The WTO in Brief, WTO, http://www.wto.org/english/thewto_e/whatis_e/ inbrief_e/inbr00_e.htm (last visited Feb. 16, 2011) [hereinafter WTO in Brief]. For an extended discussion of WTO history and structure, see WTO, UNDERSTANDING THE WTO (5th ed. 2010).

29. WTO in Brief, supra note 28.

30. Id.

31. The GATT Years: From Havana to Marrakesh, WTO, http://www.wto.org/english/ thewto_e/whatis_e/tif_e/fact4_e.htm (last visited Feb. 16, 2011).

32. $\overline{I d}$.

33. WTO in Brief, supra note 28.

34. Id.

35. Id.

36. Whose WTO Is It Anyway?, WTO, http://www.wto.org/english/thewto_e/whatis _e/tif_e/org1_e.htm (last visited Feb. 16, 2011) (explaining that, as during the GATT regime, the WTO membership does not vote; rather, decisions are made by consensus). 
regular intervals to make decisions and is the highest authority within the WTO system. ${ }^{37}$ The General Council manages the work of the WTO between ministerial conferences, administering the operations of the trade agreement, and ministerial decisions. ${ }^{38}$ Also composed of member states, the General Council acts as the organization's dispute settlement body, settling disputes between member countries. ${ }^{39}$ It also serves as the WTO's trade policy review body, analyzing the trade policies of member countries. Additional subsidiary bodies to the General Council oversee specific areas of trade, including the Council for Trade in Goods; the Council for Trade in Services; and the Council for Trade-Related Aspects of Intellectual Property Rights (TRIPS Council). ${ }^{40}$ These subject-specific councils also have subsidiary committees. ${ }^{41}$

During the Uruguay Round, developing countries negotiated some flexibility in implementing their commitments under the WTO.42 Over seventy-five percent of WTO members are developing or least-developed countries. ${ }^{43}$ Special provisions in certain WTO agreements recognize the challenges developing countries confront and permit longer time periods for such countries to implement agreements and commitments. ${ }^{44}$ Also, there are measures to encourage increased trading opportunities for developing members, ${ }^{45}$ and all WTO members are obligated to respect the trade interests of developing members. ${ }^{46}$

The WTO's intellectual property agreement, TRIPS, is a series of rules governing trade and investment in various forms of intellectual property. ${ }^{47}$ Copyrights, patents, trademarks, and geographical names, among other things, are protected under the accord. ${ }^{48}$ In response to widely varying standards of protection and minimal levels of enforcement, ${ }^{49}$ the TRIPS Agreement provides protection for intellectual property by requiring member states to grant intellectual property rights without discrimination against imported products. ${ }^{50}$ The TRIPS Agreement also imposes a general obligation on its members to "ensure that enforcement procedures ... are available under [domestic] law so

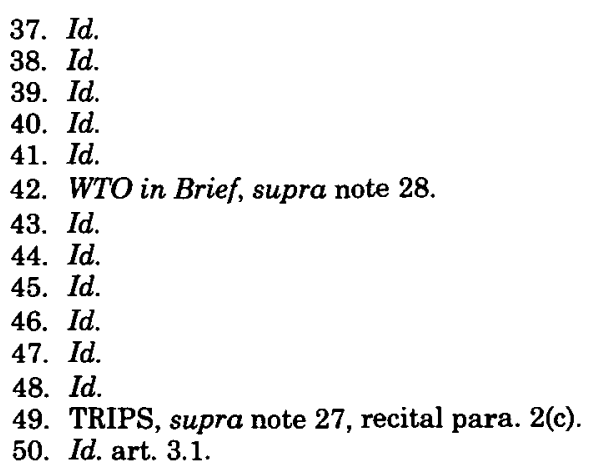


as to permit effective action against any act of infringement of intellectual property rights."51

Under earlier international accords, a country was only obligated to protect foreign intellectual property to the extent it protected local intellectual property. ${ }^{52} \mathrm{By}$ integrating intellectual property right governance into the WTO and by barring sector-based discrimination in the granting of patents, TRIPS no longer permits members to select or set different levels of protection. ${ }^{53}$ The TRIPS Agreement extended patent protection into new areas that were previously unprotected in several countries. ${ }^{54}$ With respect to patents, TRIPS imposes a twentyyear period of patent protection on all inventions, whether of products or processes, in most fields of technology with very few exceptions..$^{55}$

Developed countries argued for integration of intellectual property rights into the Uruguay Round of trade negotiations, while many developing countries opposed the integration of such rights into the global trading regime. As James Gathii has observed:

Developed countries continue to maintain that high levels of intellectual property protection provide the necessary incentive for investment in research and development, which is the best guarantee of access to essential medicines for all countries. In contrast, developing countries maintain that strict constructions of the TRIPS agreement fail to recognize the legitimate interests of intellectual property rights users, especially in the context of crises such as HIV/AIDS. ${ }^{56}$

Ultimately, developed countries prevailed on the inclusion of intellectual property and the establishment of a regime of protection,

51. Id. art. 41.1.

52. See Paris Convention for the Protection of Industrial Property art. 11, Mar. 20, 1883,828 U.N.T.S 305 (requiring countries to protect certain forms of intellectual property "in conformity with their domestic legislation").

53. See Kenneth C. Shadlen, Patents and Pills, Power and Procedure: The North-South Politics of Public Health in the WTO, 39 STUD. COMP. INT'L DEV. 76, 83 (2004).

54. Id.

55. See A Summary of the Final Act of the Uruguay Round, WTO, http://www.wto.org/ english/docs_e/legal_e/ursum_e.htm (last visited Feb. 16, 2011) (stating the TRIPS Agreement rule that inventions may be excluded from patentability if their commercial exploitation is prohibited for reasons of public order or morality; other exclusions include diagnostic, therapeutic, and surgical methods, and for certain plants and animals and biological processes for the production of plants or animals).

56. James T. Gathii, The Legal Status of the Doha Declaration on TRIPS and Public Health Under the Vienna Convention on the Law of Treaties, 15 HARV. J.L. \& TECH. 291, 294 (2002). 
while developing countries secured the concession of "transition periods" prior to their full implementation of TRIPS. Depending on the level of economic development enjoyed, member countries labeled as "least developed" were permitted longer periods of time to bring their domestic laws, procedures, and policies into compliance with the TRIPS Agreement. ${ }^{57}$

Among the most important, and opposed, reforms introduced by the TRIPS Agreement was its requirement that member countries grant patents for pharmaceutical products. ${ }^{58}$ By bringing the governance of intellectual property under the authority of the WTO, TRIPS compelled countries to increase protection and treat pharmaceutical products the same as other products. Prior to the TRIPS Agreement, many developing countries did not grant patents to pharmaceutical products (nor did many wealthier countries at earlier stages of development). ${ }^{59}$ Developing countries that did grant patents to medicines often did not grant patent protection for the twenty-year minimum term required by TRIPS. ${ }^{60}$

\section{International Human Rights Law}

Like the global agreements regulating trade, the international legal regime protecting human rights also emerged after World War II. The General Assembly of the newly formed United Nations adopted the Universal Declaration of Human Rights (UDHR) as a common standard of rights and freedoms for all, everywhere. ${ }^{61}$ Consistent with concepts of rights gaining currency at the time, the UDHR contained a range of substantive rights, including civil, political, socioeconomic, and cultural rights. The UDHR was intended to serve as the foundation for an accord that would be submitted to member countries of the United Nations for ratification.

Ultimately, provisions of the UDHR were divided between two treaties, the International Covenant on Civil and Political Rights

57. INFo. \& MEdia RELATIONS Div., WTO, FACTS SheET: TRIPS AND PHARMACEUTICAL PATENTS 7 (2006), http://www.wto.org/english/tratop_e/trips_e/tripsfactsheet_pharma_ 2006_e.pdf (last visited Jan. 19, 2011).

58. See TRIPS, supra note 27 , art. 27.1 (stating that patents shall be available and patent rights enjoyable without discrimination as to the place of invention, the field of technology, and whether products are imported or locally produced); see also Shadlen, supra note 53, at 83.

59. See Shadlen, supra note 53 , at 83-84.

60. Id.

61. Universal Declaration of Human Rights, G.A. Res. 217A, U.N. GAOR, 3d Sess.,1st Plen. Mtg., U.N. Doc. A/810 (Dec. 10, 1948) [hereinafter UDHR]. 
(ICCPR) 62 and the International Covenant on Economic, Social, and Cultural Rights (ICESCR). ${ }^{63}$ These two principal rights covenants explain and expand upon the basic rights contained in the UDHR. The two covenants establish monitoring bodies that review the regular status reports made by member countries on the measures that their governments have adopted and the progress made in realizing the rights included in the covenants. These monitoring bodies also periodically issue General Comments. These General Comments of the treaty bodies provide further substantive content to the rights enumerated in international human rights legal instruments by outlining state obligations and offering normative explanations of the entitlements associated with a given right. ${ }^{64}$

Some scholars from developing countries have challenged the universality of human rights, noting that, from their inception, international human rights legal instruments failed to include the perspectives of non-European nations. ${ }^{65}$ It must be noted that much of the Global South was under colonial rule at the time when both the GATT and United Nations were founded and their respective global rules on trade and human rights were formulated. United Nations membership in 1948 included only fifty-six states. ${ }^{66}$ Further, some scholars have argued that in certain cultural contexts, the perception of rights may depart from the Western liberalism that underlies much of the international legal regime of human rights. ${ }^{67}$ For example, many of the rights in the international legal instruments can be read as elevating the individual's interests over and above those of the

62. International Covenant on Civil and Political Rights, G.A. Res. 2200A, at 52, U.N. GAOR, U.N. Doc. A/6316 (Dec. 1966).

63. International Covenant on Economic, Social, and Cultural Rights, G.A. Res. 2200A, at 49 , U.N. GAOR, U.N. Doc. A/6316, 993 U.N.T.S. 3 (Jan. 1976) [hereinafter ICESCR].

64. See Kerstin Mechlem, Treaty Bodies and the Interpretation of Human Rights, 42 VAND. J. TRANSNAT'L L. 905, 908 (2009).

65. See, e.g., Makau Mutua, The Complexity of Universalism in Human Rights, in Human Rights With Modesty: The Problem of UnIVERSAlism 51 (Andras Sajo ed., 2004).

66. Henry J. Steiner, Phillip Alston, \& Ryan GoOdman, INTERnational Human RightS IN CONTEXT: LAW, POLITICS, MORALS 135 (3d ed. 2008).

67. For examples, see the articles in the collection HUMAN RIGHTS: CULTURAL AND IdeologicAl Perspectives (Adamantia Pollis \& Peter Schwab eds., 1979) (investigating the relevance of Western conceptions of human rights embodied in the UDHR in nonWestern societies); the articles in the collection HUMAN RIGHTS IN CROSS-CULTURAL PERSPECTIVES: A QUEST FOR CONSENSUS (Abdullahi Ahmed An-Na'im ed., 1992) (discussing the cultural legitimacy of international standards of human rights); Jack Donnelly, Human Rights and Western Liberalism, in HUMAN RIGHTS IN AFRICA: CROSSCUltural Perspectives 31 (Abdullahi Ahmed An-Na'im \& Francis M. Deng eds., 1990); and Bilahari Kausikan, Asia's Different Standard, FOREIGN POL'Y, Autumn 1993, at 24, 25 . 
community. Because individual liberties have been elevated over communal interests in human rights discourse, discussions of rights can be seen to have displaced discussion of responsibilities. In cultures where emphasis is placed on obligations and duties to the community, the pursuit of individual self-interest to the exclusion of others is not in concert with cultural norms.

While the international legal instruments that comprise the International Bill of Rights contain civil, political, and socioeconomic rights, socioeconomic rights have met with greater resistance. For some, socioeconomic rights are seen as the wrong sort of rights. ${ }^{68}$ Contrast, for instance, the ease with which governments that censor speech or imprison individuals without a fair trial can be identified as abusing rights. On the other hand, it is not as easy to identify a victim, violator, and remedy when an individual is illiterate or suffers from ill health. In part, because socioeconomic rights have not fit the classic frame of what a human rights violation is supposed to look like, they have not traditionally received the same international attention that civil and political rights have enjoyed historically.

International law, as well as the constitutions of many countries, including those of South Africa, India, and Brazil, recognizes health as a basic right. ${ }^{69}$ Article 25 of the UDHR recognizes a right to health,

68. Special Report: Righting Wrongs - Human Rights, ECONOMIST, Aug. 18, 2001, at 18 20 (arguing that "too many rights may well make a wrong"); see also Michael J. Dennis \& David P. Stewart, Justiciability of Economic, Social, and Cultural Rights: Should There Be an International Complaints Mechanism to Adjudicate the Rights to Food, Water, Housing, and Health?, 98 AM. J. INT'L L. 462, 514 (2004) ("[R]ights and obligations contained in the ICESCR were never intended to be susceptible to judicial or quasi-judicial determination. The negotiator and drafters ... . well understood the differences between [civil, political, and socioeconomic rights] . . . Those differences have not disappeared.").

69. The South African Constitution provides:

27(1): Everyone has the right to have access to-

(a) health care services, including reproductive health care

S. AFR. CoNST.art. 27(1), 1996. The Indian Constitution provides:

47. Duty of the State to Raise the Level of Nutrition and the Standard of Living and Improve Public Health

The State shall regard the raising of the level of nutrition and the standard of living of its people and the improvement of public health as among its primary duties....

INDIA CONST. art. 47. The Brazilian Constitution provides:

Article 196. Health is a right of all and a duty of the State and shall be guaranteed by means of social and economic policies aimed at reducing the risk of illness and other hazards and at the universal and equal access of actions and services for its promotion, protection and recovery.

Constituiçāo Federal [C.F.] [Constitution] art. 196 (Braz.). 
including "medical care and necessary social services."70 Expanding on the content of the health right, Article 12 of the ICESCR proclaims the right of everyone to "the enjoyment of the highest attainable standard of physical and mental health."71 To meet their obligations to guarantee this right, governments must, among other things, take steps to prevent, treat, and control epidemic disease. ${ }^{72}$ International law does not limit the right to health only to healthcare services; rather, "the right to health embraces a wide range of socio-economic factors that promote conditions in which people can lead a healthy life, and extends to the underlying determinants of health . . . safe and healthy working conditions, and a healthy environment."73 Accordingly, governments are also responsible for creating the social conditions to make medical service and attention accessible. ${ }^{74}$

In recognition of the fact that many countries have limited resources that may make government efforts to ensure the right to health for all immediately virtually impossible, the ICESCR, unlike the ICCPR, contains a provision permitting "progressive realization" of the health right over an unspecified period of time. ${ }^{75}$ This qualification notwithstanding, governments are legally obligated to "expeditiously and effectively"76 advance the right to health by taking "deliberate, concrete and targeted" measures to achieve its realization. 77

The acts or omissions of a state may violate the health right. Under international law, implementing laws that are patently irreconcilable with enabling realization of the health right would constitute a violation. Revoking laws essential to enabling the realization of the right to health would similarly constitute a violation. ${ }^{78}$ Failure to devise health policies or to enforce regulations tied to health or healthcare would constitute omissions in violation of the right to health as well. ${ }^{79}$

In its General Comment, the U.N. Committee on Economic, Social, and Cultural Rights (UNCESCR), the monitoring body for the ICESCR, notes that while "the right to the highest attainable standard of health" is not a right to be healthy, it does contain certain freedoms and

70. UDHR, supra note 61 , art. 25.

71. ICESCR, supra note 63, art. 12.1 .

72. U.N. Econ. \& Soc. Council [ECOSOC], Comm. on Econ., Soc., \& Cultural Rts., The Right to the Highest Attainable Standard of Health, I 44, U.N. Doc. E/C.12/2000/4 (Aug. 11, 2000).

73. Id. ๆ 4.

74. $I d . ~ ๆ ๆ ~ 43-44$.

75. Id. ๆ 30 .

76. Id. ๆ 31 .

77. Id. I 30.

78. Id. ๆI 46-49.

79. Id. ๆ 49 . 
entitlements. ${ }^{80}$ People are free to control their bodily integrity and remain free to refuse nonconsensual medical treatment and experimentation. People are also entitled to enjoy certain social determinants of health. The UNCESCR has interpreted the right to health as requiring that governments take measures to ensure that the social conditions are created to assure that appropriate healthcare is available and accessible. ${ }^{81}$

In sum, if it is to be realized, the right to health under international law requires performance and active intervention by the government and other organs of society to improve the material and institutional preconditions supporting the ability of an individual to obtain his or her optimum health. Significantly, a violation of the right to health can also occur when a government fails to regulate private nongovernmental entities with the power to impede realization of the highest attainable standard of health for others. ${ }^{82}$

\section{A Clash of Competing Commitments}

While there are many factors in developing countries that may influence the social determinants of the health of the country's population, the failure to ensure access to essential medicines remains at odds with obligations to respect, protect, and promote the human right to health. Access to medicines also depends on many factors, not the least of which is cost. The high cost of medicines is a significant factor for many countries in the Global South that confront the challenge of epidemic disease.

The exclusive monopoly that owners of intellectual property enjoy for a period of time with respect to the manufacture, marketing, sale, and distribution of the medicines they produce permits pharmaceutical corporations to demand higher prices for their products. The high prices of patent-protected pharmaceuticals place essential medicines beyond the reach of many developing countries. ${ }^{83}$

The connection between the costs of essential medicines and the international patent protections required by TRIPS was recognized and raised by countries in the Global South, particularly since several were

80. Id. ๆ 8.

81. Id.

82. Id. ๆ 51.

83. Daniel Waniau Muriu, Third World Resistance to International Economic and Structural Constraints: Assessing the Utility of the Right to Health in the Context of the TRIPS Agreement, 11 INT'L COMM. L. REV. 409, 411 (2009). 
situated at the epicenter of the global AIDS epidemic. ${ }^{84}$ It took civil society activists in the Global South to frame the problem as one of a denial of the fundamental human right to health, however, to bring scrutiny to the international system of intellectual property protection.

These competing obligations to protect patents on pharmaceutical products on one hand, and public health on the other, set the stage for a clash of commitments in capitals across the Global South. Countries now obligated to adhere to the TRIPS Agreement and respect intellectual property, while protecting the human rights of their citizens and others within their jurisdiction, confronted a challenge. Events in South Africa brought into sharp relief this clash of competing commitments to provide healthcare to AIDS patients and to protect the property interests of the global pharmaceutical industry. ${ }^{85}$

84. See, e.g., James Thuo Gathii, Third World Perspectives on Global Pharmaceutical Access, in ETHICS AND THE PhaRmaceutical Industry 336 (Michael A. Santoro \& Thomas M. Gorrie eds., 2005); Anna Lanoszka, The Global Politics of Intellectual Property Rights and Pharmaceutical Drug Politics in Developing Countries, 24 INT'L POL. SCI. REV. 181,190 (2003).

85. Because the primary purpose of this article is to offer an account of how a social movement and social impact litigation influenced the positions of government in the Global South, a full discussion of the competing perspectives on patent protection, innovation, and access is beyond the scope of this article. However, there is a growing literature questioning the conventional wisdom that strong patent protection promotes innovation and therefore access to medicines in the context of the Global South. See, e.g., E. Richard Gold et al., Are Patents Impeding Medical Care and Innovation?, PLoS MED., Jan. 5, 2010; Cynthia M. Ho, Unveiling Competing Patent Perspectives, 46 Hous. L. REV. 1047,1060 (2009) (" $[\mathrm{I}] \mathrm{t}$ is widely documented that patent rights do not promote research into so-called 'neglected diseases' that primarily afflict poor countries that cannot afford to pay a patent premium."); Kevin Outterson, Patent Buy-Outs for Global Disease Innovations for Low-and Middle-Income Countries, 32 AM. J.L. \& MED. 159, 160 (2006) (concluding that the "global burden of disease falls most heavily where the market is least attractive"); Ann Weilbaecher, Diseases Endemic in Developing Countries: How to Incentivize Innovation, 18 ANNALS HEALTH L. 281, 283 (2009) (addressing the "inadequacy of research and development for diseases that disproportionately affect people in developing countries" and analyzing "how the patent system can inhibit innovation of new drugs for neglected diseases"). Other commentators are considering alternatives to promote innovation and increase access to medicines. See, e.g., J. Benjamin Bai et al., Transcript, From Infringement to Innovation: Counterfeiting and Enforcement in the BRICS, 5 NW. J. TECH. \& INTELL. PROP. 525, 534-38 (2007) (reproducing the transcript of Northwestern Professor Yi Qian's discussion of her recent work, which notes that the postTRIPS period has not stimulated innovation for diseases specific to developing countries and proposes a patent system appropriate to develop levels and country-specific needs); Tim Hubbard \& James Love, A New Trade Framework for Global Healthcare R\&D, PLoS Biology, Feb. 17, 2004, at 147, 148 (noting the low rate of patents and research in diseases afflicting the poor and suggesting an alternative mechanism to promote innovation); Amy Kapczynski et al., Addressing Global Health Inequities: An Open Licensing Approach for University Innovations, 20 BERKELEY TECH. L.J. 1031, 1090-1108 (2005) (describing equitable access licensing); Jed Odermatt, Investigating New Models of Pharmaceutical Innovation to Protect the Human Right to Health (ELSA Selected Papers 


\section{Community Collective ACtion: Domestic Rights Litigation}

Having explained the clash between legal commitments to abide by TRIPS and protect intellectual property rights and to create the social conditions necessary for realization of the right to health, this part presents the legal and political struggle in South Africa over access to medicines as an example of actors in the Global South prevailing on the point that intellectual property rights must yield to the right of a country to protect its population. ${ }^{86}$

In 1997, under then-President Nelson Mandela, the South African government enacted the Medicines and Related Substances Control Amendment Act No. 90, in significant part to protect the health of the public by making essential medicines more affordable. ${ }^{87}$ To this end, among other things, the Act empowered the country's Minister for Health to determine whether to permit parallel imports of patented drugs. 88 The Act permitted the manufacture of generic HIV/AIDS drugs and encouraged the promotion of generic alternatives by requiring pharmacists to "inform all members of the public about the benefits of the substitution for a branded medicine of an interchangeable multisource medicine." 89 Price control measures were also permitted under the Act, whereby a pricing committee appointed by the Minister of Health would regulate a transparent system of published pricing. ${ }^{90}$

The Pharmaceutical Manufacturers' Association of South Africa (PMA), a coalition of the local subsidiaries of several major multinational pharmaceutical corporations, brought suit in the High Court in Pretoria challenging the South African government's legislative efforts to increase access to medicine. ${ }^{91} \mathrm{PMA}$ argued that the government's proposed reforms in the Medicines Act would constitute a

on European Law, 2009), http://www.elsa.org/fileadmin/user_upload/elsa_international/ PDF/SPEL/SPEL09_JED_ODERMATT.pdf.

86. In my view, the value of South Africa's struggle and the subsequent debates with and within the Global South concerning access to medicines and international intellectual property requirements have highlighted the competing obligations on countries, in which legal obligations potentially in conflict with the right to health must coexist. Because both the international intellectual property and human rights legal regimes are likely to remain, ultimately any future compromises between these apparently competing legal priorities must consider the needs of domestic populations burdened by disease.

87. Medicines and Related Substances Control Amendment Act 90 of 1997 (S. Afr.).

88. Id. $\S 15 \mathrm{C}(\mathrm{b})$.

89. Id. $\S 22 \mathrm{~F}(1)(\mathrm{a})$.

90. Id. $\S 22 \mathrm{G}$.

91. Pharm. Mfrs.'Ass'n of S. Afr. v. President of the Republic of S. Afr., Case no. 4183/98, High Court of South Africa (Transvaal Provincial Division). 
violation of their rights under the South African Constitution. ${ }^{92}$ The Association also argued that South Africa's statute was in breach of the government's TRIPS Agreement obligations. ${ }^{93}$

Specifically, PMA complained that the Act would in effect enable and authorize the Minister of Health "to deprive owners of intellectual property in respect of pharmaceutical products . . . [and] alternatively to expropriate such property without any provision for compensation to be paid in respect thereof." 94 The PMA principally advanced an equality argument alleging that the Act was in conflict with South Africa's constitutional guarantee of equality because it would permit the government "to discriminate in favour of imported medicines to the detriment of the manufacturers of local products."95 Further, the PMA alleged that the Act "discriminates unfairly in favor of the manufacturers of products qualifying as interchangeable multi-source medicines of a prescribed medicine, and to the detriment of the manufacturer of such prescribed medicine." 96

South Africans living with HIV and AIDS opposed the industry lawsuit, asserting that industry efforts to block legislation intended to increase access to medicines would threaten their rights to health, dignity, and life. ${ }^{97}$ The Treatment Action Campaign (TAC) became the industry's principal opponent. TAC is a voluntary association of people with HIV/AIDS and other allies, including their friends, families, and healthcare providers. It also enjoys the support of trade unions, churches, and international nongovernmental organizations. In early 2001, TAC organized an interfaith prayer service and march for treatment access to increase public awareness of the PMA case and condemn the pharmaceutical companies who were delaying

92. Henri E. Cauvin, Access to AIDS Drugs at Issue in South African Trial This Week, N.Y. TIMES, Mar. 5, 2001, at A7; see also Jennifer Joni, Access to Treatment for HIV/AIDS: A Human Rights Issue in the Developing World, 17 CONN. J. INT'L L. 273, $276-77$ (2002); Sarah Joseph, Pharmaceutical Corporations and Access to Drugs: The "Fourth Wave" of Corporate Human Rights Scrutiny, 25 HUM. RTS. Q. 425, 443 (2003).

93. Notice of Motion, Pharm. Mfrs.'Ass'n of S. Afr. v. President of the Republic of S. Afr., Case no. 4183/98, High Court of South Africa (Transvaal Provincial Division), available at http://cptech.org/ip/health/sa/pharmasuit.html.

94. Id. 72.3.

95. Id. ๆ 3.2 .

96. Id. 74.2 .

97. David Barnard, In the High Court of South Africa, Case No. 41238/98: The Global Politics of Access to Low-Cost AIDS Drugs in Poor Countries, 12 KENNEDY INST. ETHICS J. 159, 165 (2002); Nathan Geffen, Applying Human Rights to the HIV/AIDS Crisis, CARNEGIE COUNCIL FOR ETHICS IN INT'L AFF., May 6, 2001, http://www.carnegiecouncil.org/resources/ publications/dialogue/2_06/articles/646.html. 
implementation of the Medicines Act through the litigation. ${ }^{98}$ The street protests started by TAC against "profiteering pharmaceutical empires" in South Africa eventually gained solidarity supporters around the world. ${ }^{99}$

Over the objection of the PMA, TAC was granted leave from the Pretoria High Court to be admitted to the lawsuit as amicus curiae in 2001. The papers filed by TAC in the case came to capture the country's attention and redirect the public discourse on access to medicine. As Mark Heywood, Head of the AIDS Law Project at University of Witwatersrand in Johannesburg, South Africa, observed at the time, the TAC "amicus application functioned simultaneously as legal argument and advocacy tool." 100 With TAC's entry into the case, the litigation became an organizing avenue for AIDS activists and quickly attracted international media attention.

Like the PMA, TAC also framed its arguments in the language of rights and urged the Court to consider "the rights to life, dignity and access to health care services"101 as enshrined in the South African Constitution and numerous international human rights agreements. ${ }^{102}$ Like the UDHR, the South African Constitution includes civil and political rights and social and economic rights in a single undivided document. South African Constitutional Court decisions on socioeconomic rights have affirmed that civil, political, and socioeconomic rights are interrelated and mutually supporting. ${ }^{103}$ There is a rich and growing literature by South African legal scholars and other commentators on the substantive content of socioeconomic rights in the country's constitution. ${ }^{104}$

98. Treatment Action Campaign Application to be Admitted as Amicus Curiae, ๆ 10, Pharm. Mfrs.' Ass'n of S. Afr. v. President of the Republic of S. Afr., Case no. 4183/98, High Court of South Africa (Transvaal Provincial Division).

99. Id.

100. Mark Heywood, Debunking 'Conglomo-talk': A Case Study of the Amicus Curiae as an Instrument for Advocacy, Investigation and Mobilisation, 5 LAW, DEMOCRACY \& DEV. 133, 147 (2001).

101. See Heads of Argument on Behalf of the Treatment Action Campaign, $\$ 3.13$, Pharm. Mfrs.' Ass'n of S. Afr. v. President of the Republic of S. Afr., Case no. 4183/98, High Court of South Africa (Transvaal Provincial Division), available at http://www.tac.org.za/ Documents/MedicineActCourtCase.htm [hereinafter TAC Heads of Argument].

102. Section 11 of the Constitution provides: "Everyone has the right to life." Section 10 of the Constitution provides: "Everyone has inherent dignity and the right to have their dignity respected and protected." Section 27 of the Constitution provides that everyone has the right to have access to healthcare services. S. AFR. CoNST., 1996.

103. See, e.g., Gov't of the Republic of S. Afr. v. Grootboom, II 23-24 (2000) (Constitutional Court of S. Afr.).

104. See, e.g., Mark Kende, The South African Constitutional Court's Construction of Socio-Economic Rights: A Response to Critics, 19 CONN. J. INT'L L. 617 (2004); Marius 
TAC argued that there were constitutional and international legal obligations on the South African government to provide inexpensive access to drugs, particularly in the context of the country's AIDS crisis. 105 TAC dismissed industry arguments that special initiatives were sufficient:

As for the initiatives by certain members of the PMA to provide medicines at cheaper rates, these initiatives are entirely at the whim of the manufacturers concerned and reduce patients to the recipients of charity. Initiatives of this sort can as easily be withdrawn as they are made. Hence, powers of parallel importation and generic substitution, as well as price control are legitimate means to achieve price reduction and other legitimate objectives. ${ }^{106}$

Like the PMA, TAC argued that the Court was bound to consider international law in its determination. Unlike the PMA, which appealed only to TRIPS provisions, TAC pointed to other international sources. Specifically, TAC appealed to a variety of international human rights instruments. Citing provisions pertinent to the rights to life, dignity, and health in international instruments that South Africa had either signed or ratified, such as the UDHR, the ICESCR, the Convention on the Rights of the Child, and the Convention on the Elimination of All Forms of Discrimination Against Women, TAC argued:

In the context of a case such as the present, it is quite clear that having regard to the nature and scale of the HIV/AIDS epidemic there is a compelling case to be made that the State is under a duty both under the Constitution and at international law to ensure adequate access to health care. ${ }^{107}$

TAC defended the government's Medicines Act as an effort to meet its binding legal obligations. TAC also defended the Medicines Act as consistent with provisions of TRIPS that permit WTO members to amend or enact laws, including measures necessary to protect public

Pieterse, Resuscitating Socio-Economic Rights: Constitutional Entitlements to Health Care Services, 22 S. AFR. J. HUM. RTS. 473 (2006); Jeanne M. Woods, Justiciable Social Rights as a Critique of the Liberal Paradigm, 38 TEX. INT'L L.J. 763 (2003).

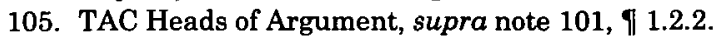

106. Id. ๆ 2.16.

107. $I d$. ๆ 3.39 . 
health and promote the public interest in sectors of vital importance to development. 108

The PMA case came to be understood as a contest between the "private interests of the pharmaceutical industry" and "people's lives and public interest." 109 Moreover, South Africa received considerable support from advocacy and AIDS activists in the Global North. Arguably, some of the sympathy for South Africa's position in the litigation was due to the suffering and strength of South Africans seen around the world. 110 The further maintenance of a lawsuit against a developing country, the gross domestic product of which would likely be far below the combined annual profits of the corporations challenging it, became untenable.

The Court never addressed the clash or conflict between the competing rights asserted by the PMA and TAC because the corporations involved elected to withdraw the lawsuit unconditionally. The PMA's decision to withdraw its lawsuit left South Africa free to implement its Medicines Act. Commentators have attributed the PMA's decision to drop the suit to international public outrage. 111 When the pharmaceutical industry dropped its lawsuit, its decision to do so was seen as a defeat for efforts to expand intellectual property rights to the exclusion of the experiences of AIDS patients and HIV-positive people and their right to health. This early victory, credited to TAC's intervention in the case, ${ }^{112}$ encouraged the emerging access to affordable medicines movement to grow beyond South Africa's borders. ${ }^{113}$ People in the Global South put more pressure on their governments to push for changes at the international level.

Although it never resulted in a judgment or a resolution between the competing interests of private industry's intellectual property rights

108. Id.; see also TRIPS, supra note 27, art. 8 ("Members may, in formulating or amending their laws and regulations, adopt measures necessary to protect public health and nutrition, and to promote the public interest in sectors of vital importance to their socio-economic and technological development, provided that such measures are consistent with the provisions of this Agreement.").

109. See, e.g., Tshimanga Kongolo, Public Interest Versus the Pharmaceutical Industry's Monopoly in South Africa, 4 J. WORLD INTELL. PROP. 609, 610 (2001); Barnard, supra note 97 , at 165 .

110. Susan K. Sell, TRIPS and the Access to Essential Medicines Campaign, 20 WIS. INT'L L.J. 481, 511 (2002).

111. See, e.g., Ellen F.M. 't Hoen, TRIPS, Pharmaceutical Patents and Access to Essential Medicines: Seattle, Doha and Beyond, in PERSPECTIVES ON HEALTH AND HUMAN RIGHTS 206 (Sofia Gruskin et al. eds., 2005) (attributing the Pharmaceutical Manufacturers' Association's decision to drop the litigation to public outcry); Lanoszka, supra note 84 , at 192; Muriu, supra note 83 , at 418 .

112. Muriu, supra note 83 , at 418 .

113. Id. 
and the public international human right to health, the PMA case was instrumental in putting the access to medicines issue on the international human rights and public health agendas. Events in South Africa changed the plot from a tale of pirates engaged in the theft of intellectual property to a story about the people and patients. The end of the PMA case also marked a major turning point in the conflict over the terms of the TRIPS Agreement. ${ }^{114}$

\section{COUNTRY COALITION BUILDING: INTERNATIONAL RIGHTS ARTICULATION AND INTERNAL POLITICS}

The international access to medicines movement reframed the debate on TRIPS as a system that privileged profits over people. The HIV/AIDS crisis in Africa offered a perspective that challenged the presentation of the TRIPS Agreement as merely a measure to protect "private property from pirates." 115 The PMA case, as well as the political organization around the case, expanded the scope of the debate over international intellectual property protection to include some consideration of human rights claims.

Other international institutions outside the WTO entered the conversation and expressed concern that intellectual property protection for essential medicines could serve as an impediment to rights realization. ${ }^{116}$ The United Nations Sub-Commission on Human Rights adopted a resolution on intellectual property outlining the implications of patented pharmaceuticals for the enjoyment of the right to health. ${ }^{117}$ The WHO also addressed the effects of strict, standardized international intellectual property protection on access to medicines. The WHO passed numerous resolutions on the importance of access to essential

114. Sell, supra note 110, at 511 (describing how street protests and pictures of "grim televised images of dying mothers and babies" damaged perceptions of industry).

115. Muriu, supra note 83 , at 419 .

116. For a discussion of the global access to medicines campaign and interventions by other international institutional actors, see $i d$.

117. ECOSOC, Comm'n on Hum. Rts., Sub-Comm'n on the Promotion \& Prot. of Hum. Rts., Intellectual Property Rights and Human Rights, Res. 2000/7, U.N. Doc. E/CN.4/Sub.2/RES/2000/7 (Aug. 17, 2000), available at http://www.unhchr.ch/Huridocda/ Huridoca.nsf/0/c462b62cf8a07b13c12569700046704e?Opendocument; see also ECOSOC, Comm'n on Hum. Rts., Sub-Comm'n on the Promotion \& Prot. of Hum. Rts., The Impact of the Agreement on Trade-Related Aspects of Intellectual Property Rights on Human Rights 12, U.N. Doc. E/CN.4/Sub.2/2001/13 (June 27, 2001), available at http://www.unhchr.ch/ Huridocda/Huridoca.nsf/Symbol/E.CN.4.Sub.2.2001. 13.En?Opendocument (noting that patent incentives inherently lead researchers "away from 'unprofitable' diseases," such as those "that predominantly affect people in poorer countries"). For a discussion of the resolution's history, see David Weissbrodt \& Kell Schoff, Human Rights Approach to Intellectual Property Protection: The Genesis and Application of Sub-Commission Resolution 2000/7, 5 MINN. INTELL. PROP. REV. 1 (2003). 
medicines as an element of the right to health and the necessity of permitting developing countries to take advantage of flexibilities already available in the TRIPS Agreement to ensure affordability and accessibility in the interests of public health. ${ }^{118}$ In June 2001, the United Nations High Commissioner for Human Rights published a report that found "evidence to suggest that the effect of patents on affordability is significant with drug prices falling sharply when generic substitutes enter a market or compete with drugs upon patent expiry."119

\section{A. The Doha Declaration}

The PMA case and the momentum generated by the global movement, combined with the inquiries by U.N. agencies into the connection between intellectual property and public health, prompted the TRIPS Council to call a special session in 2001.120 Talks at the TRIPS Council eventually resulted in the adoption of the Declaration on the TRIPS Agreement and Public Health at the WTO's ministerial meeting in Doha. Commonly called the Doha Declaration, the Declaration on the TRIPS Agreement and Public Health is primarily a product of an alliance of countries and communities in the Global South and largely reflects the perspectives of developing countries.

The Declaration evolved from a discussion paper presented by the Africa Group countries in cooperation with other countries in the Global South. ${ }^{121}$ A coalition of civil society advocates from the public health, development, and human rights communities joined the developing country members of the WTO, led by the Africa Group along with India and Brazil, to make the Doha Declaration possible.

It is worth noting, as Valbona Muzaka does, that the Doha Declaration had "no precedents within the postwar trade regime during the nearly 60 years of its existence, not to mention the strong symbolic

118. See, e.g., WHO, Exec. Bd., Antiretrovirals and Developing Countries: Report by the Secretariat, EB 115/32 (Dec. 16, 2004), available at http:/www.who.int/gb/ebwha/pdf_files/ EB115/B115_32-en.pdf; World Health Assembly [WHA], Intellectual Property Rights,

Innovation and Public Health, WHA 56.27 (May 28, 2003), available at http://apps.who.int/gb/archive/pdf_files/WHA56/ea56r27.pdf; WHO, Exec. Bd., Ensuring Accessibility of Essential Medicines, EB 109.R17 (Jan. 18, 2002), available at http://apps.who.int/gb/archive/pdf_files/EB109/eeb109r17.pdf; WHA, Revised Drug Strategy Resolution, WHA 49.14 (1996).

119. U.N. High Comm'r for Human Rights, The Impact of the Agreement on TradeRelated Aspects of Intellectual Property Rights on Human Rights, I 43, U.N. Doc. E/CN.4/Sub.2/2001/13 (June 27, 2001).

120. Muriu, supra note 83 , at 421 .

121. Id. 
and real sense of legal and political victory it embodied for the developing countries involved and their civil society allies." 122

The Doha Declaration now stands for the proposition that member governments must implement and interpret the TRIPS Agreement in such a way that it supports public health by promoting access to existing medicines and the creation of new medicines. The Declaration provides in pertinent part:

We agree that the TRIPS Agreement does not and should not prevent Members from taking measures to protect public health. Accordingly, while reiterating our commitment to the TRIPS Agreement, we affirm that the Agreement can and should be interpreted and implemented in a manner supportive of WTO Members' right to protect public health and, in particular, to promote access to medicines for all.

In this connection, we reaffirm the right of WTO Members to use, to the full, the provisions in the TRIPS Agreement, which provide flexibility for this purpose. ${ }^{123}$

The Declaration lists the flexibilities to which member states are entitled by right to exercise as follows:

Each Member has the right to grant compulsory licenses and the freedom to determine the grounds upon which such licenses are granted. ${ }^{124}$

Each Member has the right to determine what constitutes a national emergency or other circumstances of extreme urgency, it being understood that public health crises, including those relating to HIV/AIDS, tuberculosis, malaria and other epidemics, can represent a national emergency or other circumstances of extreme urgency. ${ }^{125}$

122. Valbona Muzaka, Developing Countries and the Struggle on the Access to Medicines Front: Victories Won and Lost, 30 THIRD WORLD Q. 1343, 1344 (2009).

123. Doha Declaration, supra note 8 , If 4.

124. Id. I 5(b) (emphasis added).

125. Id. I 5 (c) (emphasis added). 
The effect of the provisions in the TRIPS Agreement that are relevant to the exhaustion of intellectual property rights is to leave each Member free to establish its own regime for such exhaustion without challenge, subject to the MFN and national treatment provisions of Articles 3 and 4. ${ }^{126}$

Of particular note is the fact that the language of the Doha Declaration is crafted in the language of rights. It speaks of the "right" of members to grant compulsory licenses and the "freedom" of members to determine what constitutes an emergency.

Without resolving the issue, the Doha Declaration also recognized "that WTO Members with insufficient or no manufacturing capacities in the pharmaceutical sector could face difficulties in making effective use of compulsory licensing under the TRIPS Agreement."127 The Council for TRIPS was charged with finding "an expeditious solution to this problem."128 A decision adopted in 2003 allows a waiver of WTO member's obligations under TRIPS such that eligible members may grant a compulsory license for pharmaceutical products for export to eligible importing members, generally those least-developed members in the Africa Group. ${ }^{129}$

\section{B. The Trio and TRIPS}

The agency exercised by activists in internal domestic politics is now being played out in international arenas by countries of the Global South. The coalition created in connection with the PMA case and the Doha Declaration appears to have endured, and now the coalition's scope has extended beyond the access to medicines issue. Cooperative engagement between South Africa, India, and Brazil subsequent to the Doha Declaration has led to the creation of a trilateral diplomatic alliance actively challenging many of the perspectives and positions of the industrialized world. 130

Arguably, the internal politics of these emerging powers, with population segments advancing human rights arguments, are informing their international political agenda. In notable measure, this has

126. Id. I 5(d) (emphasis added).

127. Id. ๆ 6.

128. $I d$.

129. The WTO General Council formalized the 2003 decision in a resolution amending TRIPS. WTO, Amendment of the TRIPS Agreement, WT/L/641 (Dec. 6, 2005), available at http://www.wto.org/english/tratop_e/trips_e/wtl641_e.htm.

130. See Chris Alden \& Marco Antonio Vieira, The New Diplomacy of the South: South Africa, Brazil, India and Trilateralism, 26 THIRD WORLD Q. 1077 (2005). 
elevated rights concerns into arenas where human rights have not previously enjoyed much prominence. As evidenced by the Doha Declaration, developing countries in the Global South made demands for rights in their negotiations, not requests for concessions. This new ability to make demands is due in large measure to the increasing influence certain emerging economies are able to exert when acting in coalition. ${ }^{131}$

In 2003, South Africa, India, and Brazil signed the Declaration of Brasilia, creating the IBSA Dialogue Forum (IBSA). ${ }^{132}$ These countries created the IBSA for the purpose of sharing strategies to address international issues of common concern to the countries and to promote cooperation in international trade, areas of defense, multilateral diplomacy, technology, social development, environmental issues, and to foster greater South-South cooperation.

The Declaration creating the IBSA also structured the Trilateral Commission, an internal institutional organization for the partnership composed of the foreign ministers of the three countries. Thus, "[b]y embedding the initiative within their respective foreign ministries," the IBSA has "rapidly institutionalized a process that [might] otherwise fall victim to the vagaries of changing political fortunes or individual interest." 133 The Trilateral Commission has continued to meet at regular intervals.

Despite their apparent distinctions, the trio of countries shares certain principles and priorities. The constitutions of all three countries contain a right to health provision. All three countries were integrally involved in the drafting of the Doha Declaration and the negotiations that led to decision on the implementation of paragraph 6 of the Doha Declaration, which in particular concerns the needs of developing countries without manufacturing capacity. All three have earned positions on the U.S. Trade Representative's Section 301 List. ${ }^{134}$

131. See Andrew Hurrell \& Amrita Narlikar, A New Politics of Confrontation? Brazil and India in Multilateral Trade Negotiations, 20 GloBal Soc'Y 415, 417-22 (2006); Peter K. Yu, Access to Medicines, BRICS Alliances, and Collective Action, 34 AM. J.L. \& MED. 345,349 (2008).

132. India-Brazil-South Africa Dialogue Forum, Brasilia Declaration, June 6, 2003, available at http://www.ibsa-trilateral.org/index.php?option=com_content\&view=article \&id=154\&Itemid=86.

133. Alden \& Vieira, supra note 130 , at 1089.

134. OfFICE OF THE U.S. TRADE REPRESENTATIVE (USTR), 2010 SPECIAL 301 RePORT (2010). Section 301 of the Trade Act of 1974 is the principal U.S. statute for identifying foreign trade barriers due to inadequate intellectual property protection. Id. at 47 . The 1988 Omnibus Trade and Competitiveness Act enhanced Section 301 with the inclusion of requirements that the U.S. Trade Representative annually evaluate the intellectual property policies and practices of foreign trading partners. Id. The USTR's annual Special 
Since the formation of IBSA, Brazil has won several concessions from many major international pharmaceutical corporations with threats to use compulsory licensing. After years of threatening to do so, in 2007, Brazil issued compulsory licenses for the noncommercial public use of the patented AIDS drug Efavirenz. ${ }^{135}$ The country's program to provide free, universal access to treatment for HIVIAIDS has reduced AIDS-related mortality by more than fifty percent and has saved millions of dollars in treatment costs for AIDS-related infections. ${ }^{136}$ India manufactures "more than a fifth of the world's generic drugs"137 and has exported generic drugs to countries burdened by the HIV/AIDS epidemic. South Africa has imported generics from the other IBSA members. Additional countries across the Global South are cooperating in order to attain a greater ability to ensure access by increasing their capabilities to conduct research, develop, produce, and distribute medicines through the Technological Network on HIV/AIDS. ${ }^{138}$

\section{AIMS AND ACHIEVEMENTS: IMPLICATIONS FOR THE INTELLECTUAL PROPERTY REGIME AND HUMAN RIGHTS}

The influence that TAC and the IBSA trio will have on reshaping international intellectual property and integrating human rights into foreign policy agendas going forward remains to be seen. For example, Daniel Wanjau Muriu argues that despite the advances of Doha, the likelihood that the right to health could ensure better outcomes in Africa is limited in light of the power and influences of competing international economic actors. ${ }^{139}$

While power asymmetry exists and likely will persist, the example of the interplay between South Africa's civil society, multinational

301 Report identifies those countries where the level of intellectual property protection does not sufficiently conform to U.S. standards. Id.

135. Yu, supra note 131, at 349; see also Thomas Eimer \& Susanne Lütz, Developmental States, Civil Society, and Public Health: Patent Regulation for HIV/AIDS Pharmaceuticals in India and Brazil, 4 REG. \& GoverNANCE 135 (2010); Matthew Flynn, Public Production of Anti-Retroviral Medicines in Brazil, 1990-2007, 39 DEV. \& CHANGE 513 (2008); Richard G. Parker, Civil Society, Political Mobilization, and the Impact of HTV Scale-up on Health Systems in Brazil, 52 J. ACQUIRED IMMUNE DEFICIENCY SYNDROMES S49 (2009).

136. Yu, supra note 131, at 349 (describing Brazil as a model for other developing countries during the TRIPS talks; it was one of ten hardliner countries that refused to expand the mandate of the GATT to cover substantive intellectual property issues).

137. Id. at 352 .

138. Michael Westerhaus \& Arachu Castro, How Do Intellectual Property Law and International Trade Agreements Affect Access to Antiretroviral Therapy?, 3 PLOS MED. 1230, 1234 (2006).

139. Muriu, supra note 83 , at 410 . 
corporations, and the country's government over the AIDS crisis has demonstrated that industry can be unwilling to risk the reproach of consumers and citizens in the Global North. In the PMA case, industry moved to redeem its standing by voluntarily ending the litigation and offering to lower prices in response to the public relations crisis created with AIDS patients and their allies who protested the industry's actions in South Africa. Moreover, the expanding alliance between South Africa, India, and Brazil indicates an increasing opportunity for integrating rights concerns into global agreements that previously were more limited in focus.

There is strong evidence that the resistance by TAC against the PMA brought down the prices of antiretroviral medicines. The cost of a triple therapy combination of antiretroviral drugs that cost the equivalent of $\$ 450$ dropped to $\$ 125$ in South Africa. ${ }^{140}$ According to USAID, the number of HIV-positive women receiving antiretroviral therapy "increased from 76,000, at the end of 2004 to 251,400 at the end of 2006."141 As a result, 47,700 infants were spared infection. ${ }^{142}$ In South America, prices fell by fifty-four percent in fourteen countries. ${ }^{143}$ The dramatic drop in prices was due in part to "decisions by pharmaceutical TNCs to cut down the prices of their patented medicines, and in some cases to offer the medicines free of charge, following the bad publicity they received in relation to the PMA case and from the global access to medicines campaign." ${ }^{144}$ Price reductions during the period were also attributed to increased competition from generic producers. ${ }^{145}$ Nevertheless, the substantive win at Doha remains difficult to implement because of cumbersome and complex procedural impediments. 146

While the success of social movement mobilization and the SouthSouth alliance is worth celebrating, without more, these movements may not ensure a sustainable reconciliation between the rights of pharmaceutical companies and the obligations of developing countries with populations in need. Despite recent developments in the direction of serving the interests of populations in need, some commentators caution that strict, strong, and standardized patent protection will

140. Id. at 423.

141. USAID, supra note 21 , at 7.

142. Id.

143. Muriu, supra note 83 , at 423.

144. Id.

145. Id.

146. Id. at 426; see also Rohit Malpani \& Mohga Kamal-Yanni, Patents Versus Patients: Five Years After the Doha Declaration 19-20 (Oxfam Int'l, Briefing Paper, 2006), available at http://www.oxfam.ca/sites/default/files/Doha5_Final\%20paper_101106.pdf. 
remain an impediment to access to medicines. ${ }^{147}$ Indeed, the battle lines have shifted. Industry and the coalition of developed countries that support their position and that pressed for inclusion of intellectual property into the WTO have moved away from the multilateral front of TRIPS and are now emphasizing incorporation of intellectual property into bilateral free trade agreements. Increasingly, developed countries have in effect achieved even stronger intellectual property protection than that contained in and contemplated by the TRIPS Agreement. In addition, corporations continue to sue developing country governments and are not ceding any ground. For example, in India, Novartis sued over its intellectual property rights. ${ }^{148}$ Eventually the case was dismissed, but unlike the collection of pharmaceutical manufacturers operating in South Africa, here the corporation never retreated from its position and continued to press for protection of its intellectual property rights. ${ }^{149}$

The TRIPS Agreement contemplates a balance between inventors and consumers. Article 7, which outlines the objectives of TRIPS, provides:

The protection and enforcement of intellectual property rights should contribute to the promotion of technological innovation and to the transfer and dissemination of technology, to the mutual advantage of producers and users of technological knowledge and in a manner conducive to social and economic welfare, and to the balance of rights and obligations. ${ }^{150}$

Emerging events in the Global South may prompt a different balance. Where before the balance tipped heavily in favor of the interests of the pharmaceutical industry, it is now counterbalanced by additional factors framed as fundamental human rights. ${ }^{151}$

A frequently articulated objection to the more flexible access strategies envisioned by the Doha Declaration offered on the part of the pharmaceutical industry is that failure to provide strong protections for intellectual property rights will ultimately result in less access.

147. Muriu, supra note 83 , at 424 .

148. See Linda L. Lee, Trials and TRIPS-ulations: Indian Patent Law and Novartis AG v. Union of India, 23 BERKELEY TECH. L.J. 281 (2008).

149. Muzaka, supra note 122 , at 1356-57.

150. TRIPS, supra note 27 , art. 7 .

151. For a discussion of recent challenges to the international intellectual property legal regime from various quarters, see Laurence $\mathrm{R}$. Helfer, Regime Shifting: The TRIPS Agreement and New Dynamics of International Intellectual Property Lawmaking, 29 YALE J. INT'L L. 1, 27-52 (2004). 
Advocates of strong patent protection for pharmaceuticals argue that aggressive patent enforcement provides the incentive for industry to invest time and capital in the research and development that leads to innovation. To the extent that industry fears it will not be able to recover costs, it will not undertake research and it will not enter developing country markets. Under this view, the actions of the South Africa, India, and Brazil alliance to advance public health through increasing access using the allowed flexibilities would serve as a disincentive for future innovation.

From a public health and human rights perspective, failure to use the flexible strategies to increase access could constitute a dereliction of sovereign duty. Offering an answer to the patent as innovation engine paradigm is beyond the scope of this article; however, other commentators have noted that the assumptions underlying justifications for strong patent protection have not been sufficiently examined empirically. Dan Burk and Mark Lemley have observed that "positions about the patent system's merits or demerits" are taken as "articles of faith" absent "hard evidence." 152 Impediments to empirical research remain because evidence is difficult to obtain. As William Fisher and Talha Syed have explained, understanding innovation incentives and assessing risks that industry will stop innovating absent high profit returns on investments in research and development requires the very information that "firms jealously guard."153 Nevertheless, the introduction of a human rights discourse has served to change the dialogue and will influence incentives going forward. Perhaps, as Debora Halbert has argued, "a language of humanitarian care that does not necessarily reject completely the idea of intellectual property" 154 will continue to emerge and make possible another path.

To the extent that the international law of intellectual property and human rights seeks standardization and sameness, perspectives from the Global South suggest that difference makes a difference. For example, with respect to bringing a different perspective to a problem, Mark Heywood writes that members of the TAC sought "to promote the idea that commodities such as medicines, that are essential for health, should be treated differently under patent law [than] commodities that do not have any intrinsic link to human dignity and well-being."155

152. Dan L. Burk \& Mark A. Lemley, The Patent Crisis and How the Courts Can RESOLVE IT 37-38 (2009).

153. William W. Fisher \& Talha Syed, Global Justice in Healthcare: Developing Drugs for the Developing World, 40 U.C. DAVIS L. REv. 581, 669 (2007).

154. Debora Halbert, Moralized Discourses: South Africa's Intellectual Property Fight for Access to AIDS Drugs, 1 SEATTLE J. SOC. JUST. 257, 286 (2002).

155. Heywood, supra note 100, at 156. 
This rebalancing has contributed to greater access and a stabilization of the epidemic. It may prompt further exploration of not just rights, but also responsibilities. What are the responsibilities of the international pharmaceutical industry in the context of a global epidemic disease that disproportionately affects people in poorer countries?

The lesson to be drawn from the South African experience and the Global South alliance of South Africa, India, and Brazil is that there is significant work that legal rights and political cooperation can do to improve the conditions of people living in the Global South. The response to resistance to aspects of the TRIPS Agreement from the Global South also teaches that the struggle will be a sustained one.

John and Jean Comaroff lament the phenomenon termed "lawfarethe resort to legal instruments" whereby:

Conflicts once joined in parliaments, by means of street protests, mass demonstrations and media campaigns, through labor strikes, boycotts, blockades and other instruments of assertion, tend more and more-if not only, or in just the same way everywhere - to find their way to the judiciary. ${ }^{156}$

In this instance, the PMA case provides an interesting case in point concerning the phenomenon of lawfare and its ability to escalate and expand.

The great risk is that anyone can wield rights as weapons. In the PMA case and its associated political events, human rights prevailed over property interests by way of having more of a moral claim and a virtual monopoly of misery associated with the AIDS crisis. Communities affected by AIDS were devastated but not defeated, and their courage compelled the industry to voluntarily abandon its assertion of property rights in the South African courts. Rights are a double-edged sword and can be wielded by both developed and developing countries. Ironically, in the PMA case it was industry that struck the first blow, asserting its right to equality under the South African Constitution had been violated by the government then headed by Nelson Mandela, a man who spent a significant portion of his life imprisoned by an Apartheid government that rejected his calls for equality.

156. Comaroff \& Comaroff, supra note 12, at 26-27. 


\section{CONCLUSION}

The manner in which the TAC, a South African civil society movement, advanced legal arguments on the right to health in opposition to a suit brought by the international pharmaceutical industry against the South African government catalyzed an international movement across the Global South that culminated in the adoption of the Doha Declaration on TRIPS and Public Health. While its implementation will remain a challenge, the success of incorporating a substantive statement of rights into a trade agreement is a strong normative foundation upon which to build further protection for the right to health. 
